\title{
Pelatihan meningkatkan pengetahuan dan keterampilan kader puskesmas dalam penerapan standar pemantauan pertumbuhan balita di Kota Bitung
}

\author{
Dewanti Evita ${ }^{1}$, Abdillah Mursyid ${ }^{2}$, Tri Siswati ${ }^{2}$
}

\begin{abstract}
Background: Growth monitoring is one of major program of nutrition improvement that emphasizes on efforts to maintain and improve nutritional status of underfives. Technically, some errors often occur such as the use of inappropriate and non-calibrated scale, errors in placing the scale, and in reading the result of weighing. To improve knowledge, skills, and compliance of cadres, it is necessary to conduct training on growth monitoring standard of underfives in order that cadres can improve the capacity in evaluating growth and improve their effectiveness and efficiency in working at the integrated post (posyandu).

Objective: To identify the effect of training to the improvement of knowledge, skills, and compliance of cadres in implementing growth monitoring standard of underfives at Bitung Municipality, North Sulawesi.

Method: The study was a quasi experiment which used non-equivalent control group design. It was carried out at Bitung Barat and Aer Tembaga Health Center of Bitung Municipality, North Sulawesi to the two groups of cadres. The experiment group consisted of 44 cadres who got training twice, each was carried out a month before the evaluation on knowledge, skills, and compliance. The control group consisted of 46 cadres that got modul of growth monitoring standard of underfives. Research instruments used were questionnaire/checklist of knowledge, skills, and compliance. The result was analyzed using Chi-Square.

Result: Training improved knowledge and skills of cadres in implementing growth standard of underfives. This was indicated from average knowledge of the experiment group during pre test as much as $0.328 \pm 0.086$, post-test 1 as much as $0.335 \pm 0.554$, post-test 2 as much as $0.328 \pm 0.106$. Average skills of experiment group during pre-test were $0.446 \pm 0.067$, post-test 1 was $0.549 \pm 0.544$, post-test 2 was $0.873 \pm 0.106$. Average compliance of the experiment group during pre-test was $0.457 \pm 1.08$, post-test 1 was $0.548 \pm 0.321$, post-test 2 was $0.542 \pm 0.365$. This was indicated from average knowledge of the control group during pre-test as much as $0.122 \pm 0.155$, post-test 1 as much as $0.154 \pm 0.856$, post-test 2 as much as $0.195 \pm 0.235$. Average skills of control group during pre-test was $0.366 \pm 0.103$, post-test 1 was $0.431 \pm 0.856$, post-test 2 was $0.426 \pm 0.235$. Average compliance of the control group during pre-test was $0.352 \pm 0.363$, post-test 1 was $0.362 \pm 0.363$, post-test 2 was $0.365 \pm 0.368$.

The result of statistical analysis in average difference was $p=0.000$ for knowledge, $p=0.000$ for skills and $p=0.004$ for compliance in post-test 2 , showing that the improvement was significant $(p<0.05)$.

Conclusion: There was significant improvement in knowledge skills and compliance of cadres who got training on the implementation of growth monitoring standard of underfives at Posyandu.
\end{abstract}

KEYWORDS: training, cadres, posyandu, growth standard of underfives

\begin{abstract}
ABSTRAK
Latar Belakang: Pemantauan pertumbuhan merupakan salah satu kegiatan utama program perbaikan gizi yang menitik beratkan pada upaya pencegahan dan peningkatan keadaan gizi balita. Secara teknis, sering ditemui beberapa kesalahan antara lain dalam menggunakan timbangan yang tidak layak dan tidak dikalibrasi dan dalam pemasangan timbangan dan pembacaan hasil. Untuk meningkatkan pengetahuan, keterampilan, dan kepatuhan kader, perlu diadakan pelatihan standar pemantauan pertumbuhan balita agar kader dapat meningkatkan kemampuan dalam menilai pertumbuhan, serta meningkatkan efektivitas dan efisiensi kerjanya di posyandu.

Tujuan: Mengetahui pengaruh pelatihan terhadap peningkatan pengetahuan, keterampilan, dan kepatuhan kader dalam menerapkan standar pemantauan pertumbuhan balita di Kota Bitung, Sulawesi Utara.

Metode:Jenis penelitian ini adalah quasi eksperimental dengan rancangan non-equivalent control group design, berlokasi di Puskesmas Bitung Barat dan Puskesmas Aertembaga, Kota Bitung, Sulawesi Utara. Kelompok perlakuan adalah kader Puskesmas Aertembaga yang berjumlah 44 orang yang mendapat pelatihan standar pemantauan pertumbuhan balita 2 kali. Setiap pelatihan dilaksanakan 2 hari dan evaluasi pengetahuan, keterampilan, dan kepatuhan 1 bulan
\end{abstract}

1Dinkes Provinsi Sulawesi Utara, Jl. 17 Agustus Manado, e-mail: dewanti_evita@yahoo.com

${ }^{2}$ Prodi Gizi Poltekkes Kemenkes Yogyakarta, Jl. Tata Bumi 3, Banyuraden, Gamping, Sleman, Yogyakarta 55293 
setelah pelatihan. Kelompok pembanding kader adalah Puskesmas Bitung Barat berjumlah 46 orang yang mendapat modul standar pemantauan pertumbuhan balita. Hasil penelitian dianalisis dengan T-test, Chi-Square dan uji multivariat. Alat penelitian adalah kuesioner/Cheklist pengetahuan, daftar tilik keterampilan, dan kepatuhan.

Hasil: Pelatihan meningkatkan pengetahuan dan keterampilan kader untuk menerapkan standar pertumbuhan balita. $\mathrm{Hal}$ ini ditunjukkan dengan nilai rerata pengetahuan kelompok perlakuan pada pretest sebesar 0,328 $\pm 0,086$, post-test

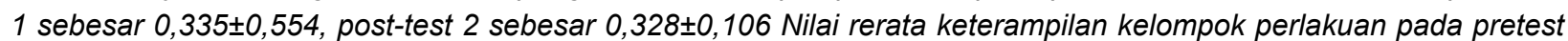

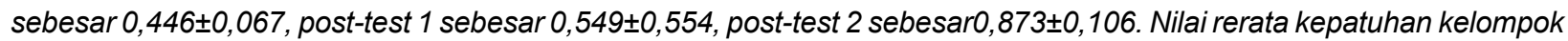

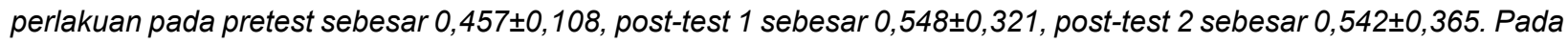

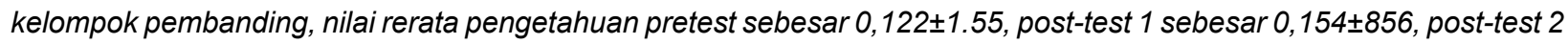
sebesar 0,195 $\pm 0,235$. Nilai rerata keterampilan pretest sebesar0,366 $\pm 0,103$, post-test 1 sebesar 0,431 $\pm 0,856$, post-test 2 sebesar 0,426 $\pm 0,235$. Nilai rerata kepatuhan pretest sebesat 0,359 0,108,post-test 1 sebesar 0,362 $\pm 0,363$, post-test 2 $0,365 \pm 0,368$. Hasil analisis statistik beda rerata antara kelompok perlakuan dan pembanding menunjukkan peningkatan yang bermakna $(p<05)$. Beda rerata peningkatan kelompok perlakuan dari pretest ke post-test 2 pengetahuan dari 0,047 menjadi 0,364, keterampilan dari 0,103 menjadi 0,427 dan kepatuhan dari 0,091 menjadi -0,085

Kesimpulan: Dengan pelatihan standar pemantauan pertumbuhan balita, pengetahuan, keterampilan, dan kepatuhan kader meningkat secara bermakna dibandingkan hanya diberikan modul.

KATA KUNCI: pelatihan, kader posyandu, standar pertumbuhan balita

\section{PENDAHULUAN}

Pos pelayanan terpadu (posyandu) merupakan salah satu bentuk pelayanan kesehatan yang diselenggarakan oleh masyarakat untuk masyarakat dengan dukungan teknis dari petugas kesehatan. Rendahnya biaya penyelenggaraan dan jangkauan yang cukup luas menjadikan posyandu alternatif pelayanan kesehatan yang perlu dipertahankan. Untuk itu pemerintah sejak tahun 1999 melakukan revitalisasi posyandu (1).Kegiatan bulan posyandu yangkualitasnya menurun menyebabkan sistem deteksi dini tidak berjalan, sehingga infomasi yang diperoleh tidak dapat digunakan sebagaimana mestinya, contohnya kasus gizi buruk tidak akan menjadi KLB (kejadian luar biasa) karena gizi buruk tidak langsung terjadi (2). Pemantauan pertumbuhan merupakan salah satu kegiatan utama program perbaikan gizi yang menitikberatkan pada upaya pencegahan dan peningkatan keadaan gizi balita. Standar pemantauan pertumbuhan balita merupakan syarat atau patokan yang harus diikuti untuk menjamin terselenggaranya pemantauan pertumbuhan dan penjaringan balita bawah garis merah (BGM) serta gizi buruk (3). Standar pemantauan pertumbuhan berguna sebagai pedoman pelaksanaan pemantauan pertumbuhan untuk menjamin kualitas pemantauan pertumbuhan dan penentuan status gizi (4). Pemantauan status gizi anak balita yang dilaksanakan di daerah-daerah, mulai dari tingkat kecamatan, kabupaten, dan provinsi dilakukan untuk memantau dan mengkaji hasil perkembangan balita yang dilakukan setiap bulan di setiap posyandu. Hasil kajian tersebut dimanfaatkan untuk menyusun rencana kegiatan posyandu di daerah masing-masing (1).

Pemantauan pertumbuhan merupakan salah satu kegiatan utama program perbaikan gizi yang menitikberatkan pada upaya pencegahan dan peningkatan keadaan gizi balita. Secara teknis, sering ditemui kesalahan menggunakan timbangan yang tidak layak dan tidak dikalibrasi serta kesalahan dalam pemasangan timbangan dan pembacaan hasil. Pelaksana posyandu adalah petugas dan masyarakat yang biasa disebut kader posyandu (5). Pengetahuan adalah kesan di dalam pikiran manusia sebagai hasil penggunaan panca inderanya (2). Keterampilan adalah kemampuan seseorang untuk menjalankan upaya yang menyangkut perilaku yang diharapkan (6). Kepatuhan atau kesediaan adalah ketika individu bersedia menerima pengaruh dari orang lain atau dari kelompok lain serta ia berharap memperoleh reaksi yang positif dari orang lain (1).

Tujuan penelitian ini adalah menganalisis pengaruh pelatihan terhadap peningkatan pengetahuan, keterampilan, dan kepatuhan kader posyandu dalam menerapkan standar pemantauan pertumbuhan balita di Kota Bitung.

\section{BAHAN DAN METODE}

Penelitian ini merupakan penelitian quasi eksperimental dengan rancangan non-equivalent control group design. Peneliti mengambil sampel secara purposif dengan cara pencuplikan kuota. Lokasi penelitian di Puskesmas Bitung Barat dan Puskesmas Aertembaga, Kota Bitung, Sulawesi Utara. Kelompok perlakuan adalah kader Puskesmas Aertembaga yang berjumlah 44 orang yang mendapat pelatihan standar pemantauan pertumbuhan balita 2 kali. Setiap pelatihan dilaksanakan 2 hari dan evaluasi pengetahuan, keterampilan, dan kepatuhan dilaksanakan 1 bulan setelah pelatihan (post-test 1) dan 2 bulan setelah pelatihan (post-test 2). Kelompok pembanding adalah kader Puskesmas Bitung Barat berjumlah 46 orang yang mendapat modul standar pemantauan pertumbuhan balita. Pengambilan data dilakukan selama bulan Februari sampai Januari 2008. 
Data pengetahuan dikumpulkan dengan mengunakan kuesioner dan data untuk melihat keterampilan dan kepatuhan menggunakan daftar tilik.

Data yang telah dikumpulkan diolah dengan menggunakan analisis statistik Chi-Square untuk melihat perbedaan peningkatan pengetahuan, keterampilan, kepatuhan sebelum dan sesudah diberi pelatihan terhadap kader tentang standar pemantauan pertumbuhan, juga menganalisis beda pengetahuan, keterampilan, dan kepatuhan antara kelompok perlakukan dan kelompok pembanding eksternal sebelum dan sesudah diberi pelatihan.

\section{HASIL DAN BAHASAN}

\section{Karakteristik subjek penelitian}

Karakteristik subjek penelitian menurut kelompok dapat dilihat pada Tabel 1. Berdasarkan Tabel 1, hasil pengukuran umur subjek terdapat variasi antara 20-40 tahun. Sebagian besar subjek berada pada kelompok umur 36-40 tahun, yaitu sebanyak 20 orang $(45,5 \%)$ pada kelompok perlakuan dan 24 orang $(54,5 \%)$ pada kelompok pembanding. Hasil pengukuran variabel pendidikan diperoleh data bahwa sebagian besar pendidikan responden adalah sekolah menengah atas (SMA) yaitu 23 orang (46\%) pada kelompok perlakuan dan 27 orang (54\%) pada kelompok pembanding. Hasil pengukuran masa kerja diperoleh data bahwa sebagian besar kader mempunyai masa kerja antara 6-9 tahun sebanyak 16 orang (40\%) pada kelompok perlakuan dan 24 orang $(60,1 \%)$ pada kelompok pembanding.

\section{Pengetahuan, keterampilan, dan kepatuhan awal subjek (saat pre-test)}

Perbandingan mean pengetahuan, keterampilan, dan kepatuhan antara kelompok perlakuan dan kelompok pembanding dilakukan untuk mengetahui perbedaan mean sebelum dilakukan pelatihan standar pemantauan pertumbuhan balita. Katergori pengukuran masing-masing variabel, baik pengetahuan, keterampilan, maupun kepatuhan pada kelompok perlakuan dan kelompok pembanding dikategorikan berdasarkan nilai standar dalam penelitian ini yaitu sebesar $80 \%$. Kader yang mempunyai tingkat baik pengetahuan, keterampilan, ataupun kepatuhan $\geq 80 \%$ baik, $80-60 \%$ dikategorikan cukup, dan $<60 \%$ dikategorikan kurang.

Berdasarkan kategori tersebut, maka dapat diketahui bahwa Tabel 2 menjelaskan proporsi pengetahuan kader tentang standar pemantauan pertumbuhan balita sebelum diberikan intervensi pada kelompok perlakuan sebagian besar cukup $(59,1 \%)$ dan pada kelompok pembanding sebagian besar kurang $(58,7 \%)$. Hasil analisis statistik Chi-Square menunjukkan nilai $p=0,326$ yang berarti bahwa proporsi pengetahuan kader pada saat pretesttidak berbeda nyata antara kelompok perlakuan dan pembanding $(p<0,05)$.

Untuk variabel keterampilan (Tabel 2), sebagian besar kelompok perlakuan memiliki keterampilan kurang $(95,5 \%)$, bahkan tidak ada satu pun yang memiliki keterampilan baik. Pada kelompok pembanding juga tidak ada kader yang memiliki keterampilan baik, sebagian besar memiliki keterampilan kurang $(89,1 \%)$. Hasil analisis statistik Chi-Square menunjukkan nilai $p=0,435$ yang menjelaskan bahwa proporsi keterampilan kader pada saat pretest tidak berbeda nyata antara kelompok perlakuan dan pembanding $(p<0,05)$.

Untuk variabel kepatuhan (Tabel 2), baik pada kelompok perlakuan maupun pembanding sebagian besar memiliki kepatuhan yang kurang, masing-masing dengan persentase $93,2 \%$ dan $87,0 \%$. Selain itu, pada kedua kelompok tidak ada yang memiliki kepatuhan yang

Tabel 1. Distribusi frekuensi karakteristik responden menurutkelompok perlakuan dan pembanding

\begin{tabular}{|c|c|c|c|c|c|c|c|c|}
\hline \multirow{3}{*}{ Karakteristik } & \multicolumn{4}{|c|}{ Kelompok } & \multirow{2}{*}{\multicolumn{2}{|c|}{ Jumlah }} & \multirow{3}{*}{$\chi^{2}$} & \multirow{3}{*}{$\mathbf{p}$} \\
\hline & \multicolumn{2}{|c|}{ Perlakuan } & \multicolumn{2}{|c|}{ Pembanding } & & & & \\
\hline & $\mathbf{n}$ & $\%$ & $\mathbf{n}$ & $\%$ & $\mathbf{n}$ & $\%$ & & \\
\hline \multicolumn{9}{|l|}{ Umur } \\
\hline $20-25$ & 6 & 40 & 9 & 60 & 15 & 16,7 & 1,77 & 0,62 \\
\hline $26-30$ & 9 & 60 & 6 & 40 & 15 & 16,7 & & \\
\hline $31-35$ & 9 & 56,2 & 7 & 43,8 & 16 & 17,8 & & \\
\hline $36-40$ & 20 & 45,5 & 24 & 54,5 & 44 & 48,9 & & \\
\hline \multicolumn{9}{|l|}{ Pendidikan } \\
\hline SMP & 21 & 52,5 & 19 & 47,5 & 40 & 44.4 & 0,38 & 0,54 \\
\hline SMA/SMEA/SMK & 23 & 46 & 27 & 54 & 50 & 55.6 & & \\
\hline \multicolumn{9}{|l|}{ Masa Kerja } \\
\hline 2-5 tahun & 9 & 75 & 3 & 25 & 12 & 13,3 & 4,64 & 0,21 \\
\hline $6-9$ tahun & 16 & 40 & 24 & 60 & 40 & 44,4 & & \\
\hline 10-13 tahun & 8 & 53,8 & 8 & 46,2 & 16 & 17,8 & & \\
\hline $14-16$ tahun & 11 & 50 & 11 & 50 & 22 & 24,4 & & \\
\hline Jumlah & 44 & 48,9 & 46 & 51,1 & 90 & 100 & & \\
\hline
\end{tabular}


Tabel 2. Distribusi pengetahuan, keterampilan, dan kepatuhan kelompok perlakuandan kelompok pembanding pada pretest

\begin{tabular}{lcccccc}
\hline \multirow{2}{*}{ Komponen } & \multicolumn{7}{c}{ Perlakuan } & Pembanding & \multirow{2}{*}{$\chi^{2}$} & \multirow{2}{*}{$\mathbf{p}$} \\
\cline { 2 - 5 } & $\mathbf{n}$ & $\mathbf{\%}$ & $\mathbf{4 6}$ & $\mathbf{\%}$ & & \\
\hline Pengetahuan & & & & & & \\
Baik $(>80 \%)$ & 1 & 2,3 & 0 & 0 & & \\
Cukup (80-60\%) & 26 & 59,1 & 19 & 41,3 & 0,951 & 0.326 \\
Kurang (<60\%) & 17 & 39 & 27 & 58,7 & & \\
Ketrampilan & & & & & & \\
Baik (>80\%) & 0 & 0 & 0 & 0 & & \\
Cukup (80-60\%) & 2 & 4,5 & 5 & 10,9 & 1,254 & 0,435 \\
Kurang (<60\%) & 42 & 95,5 & 41 & 89,1 & & \\
Kepatuhan & & & & & & \\
Baik (>80\%) & 0 & 0 & 0 & 0 & & \\
Cukup (80-60\%) & 3 & 6,8 & 6 & 13,0 & 0,486 & 0,968 \\
Kurang (<60\%) & 41 & 93,2 & 40 & 87,0 & & \\
\hline
\end{tabular}

baik. Hasil analisis statistik Chi-Square menunjukkan nilai $p=0,968$ yang membuktikan bahwa proporsi kepatuhan kader pada saat pretest tidak berbeda nyata antara kelompok perlakuan dan pembanding $(p<0,05)$.

Tidak adanya perbedaan nyata di awal penelitian ini menunjukkan kondisi awal penelitian yang sama. Penelitian quasi eksperimental dengan menggunakan purposif sampel harus mempunyai keadaan awal yang sama (7). Pengetahuan seseorang dapat dipengaruhi oleh informasi yang didapat, baik dari pembicaraan dengan teman, keluarga, membaca majalah, mendengarkan radio, maupun melihat televisi (8). Dengan demikian, pengetahuan awal responden didapat dari pengalaman belajar dan informasi yang dapat dari bersumber lain.

\section{Pengetahuan, keterampilan, dan kepatuhan subjek setelah pelatihan(post-test 1)}

Setelah 1 bulan diberikan intervensi berupa pelatihan standar pemantauan pertumbuhan balita, dilakukan post-test 1 untuk mengetahui ada/tidaknya pengetahuan, keterampilan, dan kepatuhan subjek. Hasil post-test 1 ini dapat dilihat pada Tabel 3.

Untuk variabel pengetahuan (Tabel 3), sebagian besar kelompok perlakuan (50\%) berpengetahuan baik dan kelompok perlakuan berpengetahuan cukup $(80,4 \%)$. Secara lebih rinci, proporsi pengetahuan pada kelompok perlakuan yang mempunyai pengetahuan baik berjumlah $50 \%$, sedangkan pada kelompok pembanding tidak ada. Kader yang mempunyai pengetahuan yang cukup tentang standar pemantauan pertumbuhan balita pada kelompok perlakuan berjumlah $47,7 \%$ dan pada kelompok pembanding $80,4 \%$. Kader yang kurang pengetahuannya pada kelompok perlakuan berjumlah $2,3 \%$ sedangkan pada kelompok pembanding ada 19,6\%. Hasil analisis statistik didapatkan hasil $p=0,000$ yang berarti proporsi pengetahuan kader setelah intervensi meningkat secara
Tabel 3. Distribusi pengetahuan, ketrampilan, dan kepatuhan kelompok perlakuan dan kelompok pembanding pada post-test 1

\begin{tabular}{lcccccc}
\hline \multirow{2}{*}{ Komponen } & \multicolumn{7}{c}{ Perlakuan } & Pembanding & \multirow{2}{*}{$\chi^{2}$} & $\mathbf{p}$ \\
\cline { 2 - 5 } & $\mathbf{n}$ & $\mathbf{\%}$ & $\mathbf{n}$ & $\mathbf{\%}$ & & \\
\hline Pengetahuan & & & & & & \\
Baik $(>80 \%)$ & 22 & 50,0 & 0 & 0 & 2,371 & 0,000 \\
Cukup $(80-60 \%)$ & 21 & 47,7 & 37 & 80,4 & & \\
$\quad$ Kurang $(<60 \%)$ & 1 & 2,3 & 9 & 19,6 & & \\
Keterampilan & & & & & & \\
Baik $(>80 \%)$ & 0 & 0 & 0 & 0 & 8,171 & 0,004 \\
Cukup $(80-60 \%)$ & 16 & 36,4 & 5 & 10,9 & & \\
Kurang $(<60 \%)$ & 28 & 63,6 & 41 & 89,1 & & \\
Kepatuhan & & & & & & \\
Baik $(>80 \%)$ & 0 & 0 & 0 & 0 & 0,928 & 0,080 \\
Cukup $(80-60 \%)$ & 7 & 15,9 & 7 & 15,2 & & \\
Kurang $(<60 \%)$ & 37 & 84,1 & 39 & 84,8 & & \\
\hline
\end{tabular}

* Signifikan $(p<0,05)$

bermakna $(p<0,05)$. Hal ini dapat dilihat dari penurunan jumlah kader pada kelompok perlakuan yang memiliki pengetahuan kurang dan meningkatnya kader yang berpengetahuan cukup dan baik.

Untuk variabel keterampilan (Tabel 3), baik pada kelompok perlakuan maupun kelompok pembanding memiliki keterampilan yang kurang, masing-masing $63,6 \%$ dan $89,1 \%$. Secara lebih rinci, proporsi keterampilan kader saat posttest1 pada kelompok perlakuan yang mempunyai cukup keterampilan berjumlah $36,4 \%$, sedangkan pada kelompok pembanding sebanyak $10,9 \%$. Kader yang mempunyai keterampilan kurang dalam melakukan standar pemantauan pertumbuhan balita pada kelompok perlakuan berjumlah $63,6 \%$ dan pada kelompok pembanding $89,1 \%$. Hasil analisis statistisk Fisher's exact Chi-Square didapatkan hasil $p=0,004$ yang berarti ada peningkatan pengetahuan kader setelah intervensi selama 1 bulan $(p<0,05)$. Hasil ini dapat dilihat dari bertambahnya jumlah kelompok perlakuan yang memiliki keterampilan cukup, sedangkan yang yang memiliki keterampilan kurang jumlahnya menurun.

Untuk variabel kepatuhan (Tabel 3), kader pada kelompok perlakuan yang cukup patuh ketika melaksanakan standar pemantauan pertumbuhan balita berjumlah $15,9 \%$, sedangkan pada kelompok pembanding sebanyak $15,2 \%$. Kader yang kurang patuh ketika melakukan standar pemantauan pertumbuhan balita pada kelompok perlakuan berjumlah $84,1 \%$ dan pada kelompok pembanding $84,8 \%$. Hasil analisis statistisk didapatkan hasil $p=0,008$ yang berarti proporsi kepatuhan kader setelah intervensi hampir tidak adapeningkatan secara bermakna $(p>0,05)$. Hal ini didukung data yang menunjukkan sedikitnya peningkatan (meningkat sebesar 9,1\%) kepatuhan kategori cukup pada kelompok perlakuan setelah pelatihan.

Hasil pelatihan standar pemantauan pertumbuhan balita terhadap kader posyandu telah meningkatkan 
pengetahuan dan keterampilan kader tersebut. Pengetahuan diartikan sebagai kemampuan untuk mengingat suatu materi yang telah dipelajari sebelumnya. Untuk mengukur bahwa seseorang dikatakan tahu terhadap apa yang pernah dipelajari adalah dengan melihat kemampuan menyebut, menguraikan, mendefinisikan, menyatakan, dan lain sebagainya. Semakin besar perhatian seorang terhadap sesuatu materi, semakin lama materi itu disimpan dalam ingatan. Penilaian keberhasilan belajar kader dikatakan baik bila kader mampu mencapai nilai $\geq 80 \%$ dari materi yang diberikan. Hal ini yang mendasari pengkategorian pengetahuan, keterampilan, dan kepatuhan dalam penelitian ini. Tingkat pengetahuan, keterampilan, dan kepatuhan kader $<60 \%$ dari materi dikategorikan mempunyai pengetahuan, keterampilan, dan kepatuhan rendah. Untuk kader yang mempunyai nilai antara $>59 \%$ dan $<79 \%$ dikategorikan mempunyai pengetahuan, keterampilan, dan kepatuhan yang cukup. Evaluasi suatu pendidikan yaitu penilaian dikatakan baik apabila $\geq 80 \%$ dari hasil pengukuran materi pelatihan tersebut (8).

Keterampilan kader yang diharapkan dalam penelitian ini adalah keterampilan teknik dalam melaksanakan standar pemantauan pertumbuhan balita. Kepatuhan dalam penelitian ini adalah kemauan kader untuk mempraktikkan keterampilan tersebut dilapangan sesuai standar pemantauan pertumbuhan balita. Dengan melakukan kegiatan tersebut secara terus menerus dan teratur, gangguan keseimbangan gizi pada anak akan dapat diketahui secara dini dan tindakan yang tepat dapat dilakukan (9). Standar pemantauan pertumbuhan berguna sebagai pedoman pelaksanaan pemantauan pertumbuhan untuk menjamin kualitas pemantauan pertumbuhan dan penentuan status gizi (7).

\section{Pengetahuan, keterampilan, dan kepatuhan subjek setelah pelatihan (post-test 2)}

Perubahan proporsi pengetahuan, keterampilan, dan kepatuhan subjek diukur kembali setelah 2 bulan intervensi. Hasilnya dapat dilihat pada Tabel 4.

Secara garis besar, pengetahuan kelompok perlakuan pada post-test 2 ini tergolong baik $(61,4 \%)$ dan pada kelompok pembanding tergolong cukup (78,3\%). Yang mempunyai pengetahuan kurang adalah sebanyak 2,3\% pada kelompok perlakuan dan $78,3 \%$ pada kelompok pembanding. Hasil uji statistik menunjukkan bahwa adanya intervensi pada kelompok perlakuan mampu meningkatkan pengetahuan kader $(p<0,05)$.

Keterampilan kader juga menunjukkan adanya peningkatan keterampilan, dengan kelompok perlakuan yang sebagian besar memiliki keterampilan cukup dan kelompok pembanding dengan keterampilan kurang, masing-masing dengan persentase kader 56,8\% dan $82,6 \%$. Hasil analisis statistik didapat hasil $p=0,000$ yang berarti proporsi keterampilan kader setelah intervensi
Tabel 4. Distribusi pengetahuan, keterampilan, dan kepatuhan kelompok perlakuan dan kelompok pembanding pada post-test 2

\begin{tabular}{lcccccc}
\hline Komponen & \multicolumn{7}{c}{ Perlakuan } & \multicolumn{2}{c}{ Pembanding } & $\chi^{2}$ & $\mathbf{p}$ \\
\cline { 2 - 6 } & $\mathbf{n}$ & $\%$ & $\mathbf{n}$ & $\%$ & & \\
\hline Pengetahuan & & & & & & \\
Baik $(>80 \%)$ & 27 & 61,4 & 1 & 2,2 & 2,807 & 0,000 \\
Cukup (80-60\%) & 16 & 36,4 & 36 & 78,3 & & \\
Kurang (<60\%) & 1 & 2,3 & 9 & 19,6 & & \\
Ketrampilan & & & & & & \\
Baik (>80\%) & 1 & 2,3 & 0 & 0 & 2,652 & 0,000 \\
Cukup (80-60\%) & 25 & 56,8 & 8 & 17,4 & & \\
Kurang $(<60 \%)$ & 18 & 40,9 & 38 & 82,6 & & \\
Kepatuhan & & & & & & \\
Baik $(>80 \%)$ & 0 & 0 & 0 & 0 & 0,283 & 1,152 \\
Cukup (80-60\%) & 5 & 11,4 & 9 & 19,6 & & \\
Kurang $(<60 \%)$ & 39 & 88,6 & 37 & 80,4 & & \\
\hline
\end{tabular}

* Signifikan $(p<0,05)$

kedua ada peningkatan secara bermakna $(p<0,05)$. Hasil keterampilan kader dalam penelitian ini menunjukkan bahwa kelompok perlakuan pada saat pretest rata-rata mampu mengerjakan sesuai standar sebanyak 6 item dari 17 item daftar tilik. Pada saat post-test 1 meningkat menjadi 14 item dan post-test 2 menjadi 16, sedangkan kelompok pembanding sebanyak 8 item baik pada saat pretest, post-test 1 , dan post-test 2.

Peningkatan pengetahuan dan keterampilan yang terjadi pada kelompok pembanding tidak banyak mengalami perubahan karena informasi yang diperoleh kader hanya melalui modul yang diberikan tanpa bimbingan intensif, sedangkan pada kelompok perlakuan yang diberi pelatihan pengetahuan dan keterampilan meningkat secara bermakna. Pelatihan merupakan upaya meningkatkan pengetahuan, mengubah perilaku, dan mengasah keterampilan.

Berbeda dengan pengetahuan dan keterampilan, kepatuhan kader pada kelompok perlakuan makin menurun, terbukti dari peningkatan persentase kepatuhan dengan kategori kurang yang bertambah dibanding pada post-test 1 , yang semula $84,1 \%$ menjadi $88,6 \%$. Hasil analisis statistik didapatkan hasil $p=1,152$ yang berarti proporsi kepatuhan kader pada post-test 2 tidak ada peningkatan yang bermakna $(p>0,05)$.

Hasil kepatuhan kader dalam penelitian ini menunjukkan bahwa kelompok perlakuan rata-rata melaksanakan 5 item standar pemantauan balita saat pretest sedangkan pada pos-test 1 dan post-test 2 sebanyak 9 item. Pretest kelompok pembanding sebanyak 5 item sedangkan saat post-test 1 dan posttest 2 meningkat menjadi 6 item. Item kepatuhan yang samasekali tidak dilakukan oleh kedua kelompok baik saat pretest, post-test 1 dan post-test 2 adalah item mencantumkan bulan penimbangan sesuai dengan umur setiap kali balita ditimbang. Alasan kader tidak melakukan 
Tabel 5. Analisis bivariat variabel pengetahuan, keterampilan, dan kepatuhan

\begin{tabular}{|c|c|c|c|c|c|c|c|c|}
\hline \multirow{2}{*}{ Variabel } & \multicolumn{2}{|c|}{ Perlakuan } & \multicolumn{2}{|c|}{ Pembanding } & \multirow{2}{*}{ p } & \multirow{2}{*}{ OR } & \multicolumn{2}{|c|}{$95 \% \mathrm{Cl}$} \\
\hline & $\mathbf{n}$ & $\%$ & $\mathbf{n}$ & $\%$ & & & $\min$ & maks \\
\hline \multicolumn{9}{|l|}{ Pendidikan } \\
\hline SMP & 21 & 52,5 & 19 & 47,5 & 0,540 & 0,771 & 0,335 & 1,773 \\
\hline SMA & 23 & 46 & 27 & 54 & & & & \\
\hline \multicolumn{9}{|l|}{ Masa Kerja (tahun) } \\
\hline \multirow[t]{2}{*}{$2-5$} & 9 & 75 & 3 & 35 & 0,257 & 0,271 & 0,068 & 1,079 \\
\hline & 35 & 44,0 & 43 & 55,1 & & & & \\
\hline \multirow[t]{2}{*}{$6-9$} & 16 & 40 & 24 & 60 & 0,261 & 1,909 & 0,821 & 4,439 \\
\hline & 28 & 56 & 22 & 44 & & & & \\
\hline \multirow[t]{2}{*}{$10-13$} & 8 & 50 & 8 & 50 & 0,922 & 0,947 & 0,321 & 2,792 \\
\hline & 36 & 48,6 & 38 & 51,4 & & & & \\
\hline \multirow[t]{2}{*}{$14-16$} & 11 & 50 & 11 & 50 & 0,905 & 0,943 & 0,360 & 2,466 \\
\hline & 33 & 48,5 & 35 & 51,5 & & & & \\
\hline \multicolumn{9}{|l|}{ Umur (tahun) } \\
\hline \multirow[t]{2}{*}{$20-25$} & 39 & 47,6 & 43 & 52,4 & 0,420 & 1,838 & 0,421 & 8,199 \\
\hline & 5 & 62,5 & 3 & 37,5 & & & & \\
\hline \multirow[t]{2}{*}{$26-30$} & 9 & 60 & 6 & 40 & 0,346 & 0,583 & 0,189 & 1,803 \\
\hline & 35 & 46,7 & 40 & 53,3 & & & & \\
\hline \multirow[t]{2}{*}{$31-35$} & 29 & 48,3 & 31 & 51,7 & 0,881 & 1,069 & 0,445 & 2,569 \\
\hline & 15 & 50 & 15 & 50 & & & & \\
\hline \multicolumn{9}{|c|}{ Post-test 1 Pengetahuan } \\
\hline Cukup & 43 & 53,8 & 37 & 46,2 & 0,015 & 0,096 & 0.01 & 0,790 \\
\hline Kurang & 1 & 10 & 9 & 90 & & & & \\
\hline \multicolumn{9}{|c|}{ Post-test 2 Pengetahuan } \\
\hline Baik & 27 & 96,4 & 1 & 3,6 & 0,000 & 0,014 & 0,002 & 0,111 \\
\hline Cukup & 17 & 27,4 & 45 & 72,4 & & & & \\
\hline \multicolumn{9}{|c|}{ Post-test 1 Keterampilan } \\
\hline Cukup & 16 & 76,2 & 5 & 23,8 & 0,004 & 0,213 & 0,070 & 0,650 \\
\hline Kurang & 28 & 40,6 & 41 & 59,4 & & & & \\
\hline \multicolumn{9}{|c|}{ Post-test 1 Keterampilan } \\
\hline Cukup & 26 & 76,5 & 8 & 23,5 & 0,000 & 0,146 & 0,055 & 0,385 \\
\hline Kurang & 18 & 32,1 & 38 & 67,9 & & & & \\
\hline \multicolumn{9}{|l|}{ Post-test 1 Kepatuhan } \\
\hline Cukup & 7 & 50 & 7 & 50 & 0,928 & 0,949 & 0,303 & 2,967 \\
\hline Kurang & 37 & 48,7 & 39 & 51,3 & & & & \\
\hline \multicolumn{9}{|l|}{ Post-test 1 Kepatuhan } \\
\hline Cukup & 9 & 64,3 & 5 & 35,7 & 0,283 & 1,897 & 0,582 & 6,188 \\
\hline Kurang & 37 & 48,7 & 39 & 51,3 & & & & \\
\hline
\end{tabular}

* Signifikan $(p<0,05)$

hal tersebut adalah perlu waktu untuk menghitung umur balita dengan cepat.

Kepatuhan pada kedua kelompok tidak banyak mengalami perubahan yang dapat dipengaruhi oleh sikap petugas kesehatan yang tidak memberikan bimbingan teknis secara berkala. Kehadiran petugas kesehatan ke posyandu hanya untuk memantau jumlah kunjungan balita dan tidak memberi pendidikan mengenai keterampilan dan kepatuhan kader dalam melakanakan standar pemantauan pertumbuhan balita. Dengan adanya bimbingan teknis dari petugas kesehatan, kader dapat termotivasi untuk melaksanakan standar pemantauan pertumbuhan balita dengan benar. Kepatuhan atau kesediaan adalah ketika individu bersedia menerima pengaruh dari orang lain atau dari kelompok lain serta ia berharap memperoleh reaksi positif dari orang lain (6).

\section{Pengaruh pelatihan terhadap pengetahuan, keterampilan, dan kepatuhan}

Untuk mengetahui pengaruh pelatihan terhadap pengetahuan, keterampilan, dan kepatuhan dilakukan uji multivariat. Sebelum variabel-variabel dimasukan dalam analisis multivariat, terlebih dahulu dilakukan analisis bivariat. Hasil analisis bivariat dapat dlihat pada Tabel 5.

Tabel 5 menunjukkan bahwa variabel pendidikan, umur, masa kerja, dan kepatuhan kader pada post-test 1 dan kepatuhan post-test 2 tidak dapat dilanjutkan dengan 
Tabel 6. Hasil analisis regresi logistik multivariat

\begin{tabular}{|c|c|c|c|c|c|c|}
\hline \multirow{2}{*}{ Variabel } & \multicolumn{2}{|c|}{ Tahap 1} & \multicolumn{2}{|c|}{ Tahap 2} & \multicolumn{2}{|c|}{ Tahap 3} \\
\hline & $p$ & OR & $\mathbf{p}$ & OR & $p$ & OR \\
\hline $\begin{array}{l}\text { Post-test } 1 \\
\text { Pengetahuan }\end{array}$ & 0,286 & 3,308 & & & & \\
\hline $\begin{array}{l}\text { Post-test } 2 \\
\text { Pengetahuan }\end{array}$ & $0,000^{*}$ & 54,44 & 0,000 & 63,84 & 0,000 & 79,23 \\
\hline $\begin{array}{l}\text { Post-test } 1 \\
\text { Keterampilan }\end{array}$ & 0,112 & 3,36 & 0,084 & 3,61 & 0,009 & 5,80 \\
\hline $\begin{array}{l}\text { Post-test } 2 \\
\text { Keterampilan }\end{array}$ & 0,125 & 2,87 & 0,114 & 2,87 & & \\
\hline
\end{tabular}

* Signifikansi $(p<0,05)$

analisis multivariat. Variabel yang mempunyai nilai $p<0,25$ pada analisis bivariat adalah variabel yang dapat dilakukan analisis multivariat. Dalam analisis bivariat ini, pelatihan berpengaruh pada evaluasi pengetahuan dan evaluasi keterampilan pada saat post-test 1 dan post-test 2 .

Analisis multivariat digunakan untuk mengetahui pengaruh dan kemaknaan antara variabel bebas dan terikat. Hasil analisis regresi berganda pada Tabel 6 dapat dilihat dari tahap 1 sampai tahap 3.

Analisis multivariat menunjukkan bahwa pelatihan mempunyai pengaruh yang bermakna terhadap pengetahuan kader. Tahap 1 untuk mengetahui besarnya pengaruh pelatihan terhadap pengetahuan dan keterampilan saat post-test 1 dan post-test 2 . Hasil analisis tersebut menunjukkan bahwa ada pengaruh bermakna pelatihan terhadap peluang peningkatan pengetahuan kader pada post-test 2 ( $p<0,05)$, sedangkan pada post-test 1 pengetahuan serta post-test 1 dan post-test 2 tidak ada pengaruh yang bermakna $(p>0,05)$.

Tahap 2 menunjukkan pelatihan tetap mempunyai pengaruh yang bermakna terhadap pengetahuan kader saat post-test 2. Dari tahap 1 ke tahap 2 ada peningkatan peluang pengetahuan kader saat post-test 2 yaitu dari 54,447 menjadi 63,841 . Pada post-test 1 , keterampilan meningkat dari 3,36 menjadi 3,61. Dari tahap 1 ke tahap 2 post-test 2, keterampilan menunjukkan tidak ada peningkatan peluang keterampilan (cenderung tetap yaitu 2,87 ). Variabel pelatihan tetap berpengaruh secara bermakna terhadap pengetahuan kader saat post-test $2(p<0,05)$, sedangkan saat post-test 1 dan post-test 2 keterampilan tidak mempunyai pengaruh yang bermakna $(p>0,05)$.

Tahap 3 menunjukkan pelatihan tetap mempunyai pengaruh yang bermakna terhadap pengetahuan kader saat post-test 2. Dari tahap 2 ke tahap 3 ada peningkatan pengetahuan kader saat post-test 2 sebesar 15,39 (dari 63,84 menjadi 79,23 ). Variabel pelatihan tetap berpengaruh secara bermakna terhadap pengetahuan kader saat posttest $2(\mathrm{p}<0,05)$, sedangkan saat post-test 1 dan post-test 2 keterampilan tidak mempunyai pengaruh yang bermakna $(p>0,05)$.

\section{KESIMPULAN DAN SARAN}

Berdasarkan hasil penelitian, dapat diambil kesimpulan bahwa terdapat peningkatan pengetahuan keterampilan secara bermakna pada kader yang diberi pelatihan dalam menerapkan standar pemantauan pertumbuhan balita di posyandu. Pelatihan tidak memberi pengaruh yang bermakna terhadap peningkatan kepatuhan kader dalam menerapkan standar pemantauan pertumbuhan balita di posyandu.

Saran yang diberikan kepada pengelola program gizi di tingkat dinas kesehatan yaitu agar kader dapat melakukan deteksi dini gangguan pertumbuhan balita dan perlu diadakan pelatihan standar pemantauan pertumbuhan balita untuk meningkatkan pengetahuan dan keterampilan kader.

Bagi pengelola program gizi di puskesmas, perlu dilakukan pendampingan bagi kader posyandu dalam menerapkan standar pemantauan pertumbuhan balita secara berkesinambungan, sehingga standar ini dapat menjadi suatu kebiasaan.

\section{RUJUKAN}

1. Djaiman HPS. Faktor-faktor uang mempengaruhi balita berkunjung ke posyandu [serial online] 2001 [diakses 5 Agustus 2007]. Tersedia dalam: http://www.digilib. litbang.depkes.go.id.

2. Sudijono A. Pengantar evaluasi pendidikan. Jakarta: PT Raja Grafindo Persada; 1998.

3. Departemen Kesehatan RI.Standar pemantauan pertumbuhan balita. Jakarta: Depkes RI; 2005.

4. Jahari AB. Implementasi pemantauan dan promosi pertumbuhan balita (PPPB) peran pppb dalam upaya penanggulangan gizi buruk[Materi TOT standar pemantauan pertumbuhan balita CD-ROOM]. Surabaya; 2005.

5. Departemen Kesehatan RI. Buku panduan pelatihan kader posyandu. Jakarta: Dirjen Kesehatan Masyarakat Depkes RI; 2000.

6. Azwar S.Sikap manusia teori dan pengukurannya. Jakarta: Pustaka Pelajar; 2007.

7. Murti B. Prinsip dan metode riset epidemiologi. Yogyakarta:Gadjah Mada University Press; 1997.

8. Sudjana N. Penilaian hasil belajar proses belajar remaja. Bandung: PT Rosdakarya; 2004.

9. Departemen Kesehatan RI. Pemantauan pertumbuhan balita. Jakarta: Direktorat Jendral Bina Kesehatan Masyarakat Depkes RI; 2002. 